Jaroslaw MICHALAK ${ }^{\text {), }}$, Tomasz BISKUP ${ }^{1)}$, Carsten BUEHRER ${ }^{2)}$, Bogusław GRZESIK ${ }^{\text {), }}$, Szymon

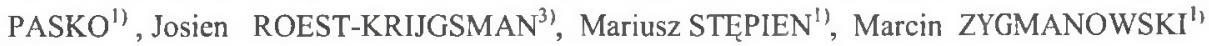

${ }^{11}$ Politechnika Śląska, Zakład Napędu Elektrycznego i Energoelektroniki

2) KEMA NEDERLAND B V

3) THRITHOR GmbH

\title{
ANALYSIS OF THYRISTOR SWITCH IN POWER CONDITIONING SYSTEM WITH SMES
}

Summary. Ensuring high level of power quality $(\mathrm{PQ})$ is one of the most important issues in supplying industry loads. There exist some critical types of loads that should be protected from voltage disturbances. If a voltage disturbance like a voltage dip or short interruption occurs, an alternative energy source is used to ensure the constant voltage amplitude across the protected load. In the described power conditioning system (PCS), a power electronic system is connected in parallel to a group of protected loads. The PCS together with the protected loads have to be disconnected from the mains in the case of the voltage dip or short interruption. This is necessary, to prevent from delivering energy to a low impedance part of the power system (the mains in such case) from energy storage that is contained in the PCS (in this situation - high temperature Superconducting Magnetic Energy Storage (SMES)). In the described system breaking the connection between the mains and the load is realized by means of a thyristor switch (TS). Disconnection and reconnection modes of the PCS operation are in detail described and analysed in the paper. To obtain a relatively low turn off time of the thyristor switch a new method of controlling the PCS is proposed that can assist turning off process of the TS and decreasing turn off time. The resynchronisation of the load voltage and the mains voltage of the PCS is also presented in the paper. It is used to limit the amplitude of the mains current after reconnection process. The influence of resynchronisation and reconnection processes on the load voltage is also analyzed. In order to prove the correctness of the designed controller simulations and experiments has been carried out. Their results are presented and discussed in the paper.

\section{ANALIZA ŁĄCZNIKA TYRYSTOROWEGO W KONDYCJONERZE ENERGII Z CEWKĄ NADPRZEWODZACA}

Streszczenie. Zapewnienie wysokiego poziomu jakości energii elektrycznej jest jednym z najważniejszych zagadnień w układach zasilania odbiorników przemysłowych. Dodatkowo istnieją wybrane układy przemysłowe, które muszą być zabezpieczone przed zaburzeniami w napięciu zasilającym. W tym przypadku, jeżeli nastapi jakiekolwiek zaburzenie (np. zapad napięcia luk krótka przerwa w zasilaniu), musi być użyte dodatkowe źródło energii, aby zapewnić ciagłość zasilania na zaciskach chronionych 
odbiorników. W przedstawionym w artykule kondycjonerze mocy, przekształtnik energoelektroniczny jest połączony równolegle do chronionych odbiorników. Kondycjoner mocy i chronione odbiorniki muszą być w tym wypadku odłączone od sieci zasilającej, co jest potrzebne ze względu na niską impedancję systemu energetycznego w przypadku wystapienia zapadu napięcia. Zachowanie połączenia $\mathrm{z}$ siecią zasilająca powoduje, że energia $\mathrm{z}$ układu kondycjonera (wraz $\mathrm{z}$ zasobnikiem $\mathrm{w}$ postaci wysokotemperaturowej cewki nadprzewodzącej (SMES)) jest dostarczana do systemu energetycznego zamiast do odbiornika. W przedstawionym systemie do odłączania zastosowano łącznik zbudowany $\mathrm{z}$ tyrystorów. Szczegółowo omówiono i przeanalizowano tryb odłączania i ponownego przyłączania odbiorników chronionych i kondycjonera do sieci zasilającej. Zaproponowano metodę wspomagania wyłączania łącznika tyrystorowego (skrócenia czasu wyłączania tyrystorów) poprzez odpowiednie sterowanie kondycjonerem mocy. Przedstawiono również proces ponownej synchronizacji napięcia odbiornika z siecią zasilająca. Proces ten pozwala na ograniczenie prądu sieci $\mathrm{w}$ chwili podłączenia chronionych odbiorników do sieci zasilającej. Przeanalizowano wpływ ponownej synchronizacji i podłączenia na napięcie i prąd w przypadku różnych odbiorników energii. Poprawność pracy układu kondycjonera wraz $z$ łącznikiem tyrystorowym została potwierdzona przedstawionymi wynikami badań symulacyjnych i laboratoryjnych.

\section{INTRODUCTION}

Increasing the power quality (PQ) is possible by using the Power Conditioning System (PCS) - Fig.1. The PCS is a bidirectional power electronic system whose main task is ensuring required level of selected parameters specifying the power quality in different operation modes. A thyristor switch (TS) in the PCS plays a crucial role. It has to be reliable and relatively fast.

The PCS is connected to the load in parallel and contains Superconducting Magnetic Energy Storage (SMES) as energy storage. The presented system was realised in the project HIPOLITY financed by the EU Fifth Framework Program (parameters describing the model of PCS: nominal power $S_{\mathrm{N}}=30 \mathrm{kV} \cdot \mathrm{A}$, nominal voltage $V_{\mathrm{N}}=400 \mathrm{~V}, 50 \mathrm{~Hz}$, nominal energy $E_{\mathrm{N}}=$ $21 \mathrm{~kJ})$.

In order to explain the role of the TS in the PCS it is necessary to describe the operation of the PCS where one can distinguish three main, steady state modes:

- Compensation mode (CM): the PCS operates as an active power filter and compensates the first harmonic reactive power and reduces higher harmonics of load currents. Additionally, it ensures symmetry of the mains currents even if loads are asymmetrical.

- Load overcurrent mode (LOM): the PCS operates as an active power filter and additionally limits the maximum value of the mains current (active current component of the mains current).

- Voltage fault mode (VFM): the PCS operates as an uninterruptible power supply (UPS) and recovers the protected load voltage. This mode will take place if a mains voltage dip or short interruption occurs.

In the compensation mode (CM) and load overcurrent mode (LOM) the PCS is connected to the mains and operates as a controlled current source. In the voltage fault mode (VFM) breaking connection between the mains and protected load is needed. The PSC operates in this mode as a voltage source due to input LC filters in PES (Fig. 1). The thyristor switch (TS) is a 
disconnecting device. Other possibilities of realising devices, disconnecting the load from the mains have been taken into account, such as a mechanical switch and switch build of IGBT transistors but the TS seems to be the best solution. The mechanical switch has a relatively long turn off time (10 ms or longer) and has the limited number of switching cycles. High current and high voltage IGBT modules have a relatively high voltage drop that causes power losses and they require using series diodes. These diodes increase conduction power losses. Thyristor realisation of the switch has been chosen because of the relatively low power losses, relatively short turn off time, reliability and low costs. The maximum turn off time of the TS is $10 \mathrm{~ms}$ (the notion "turn off time" differs from that defined and used for thyristors).

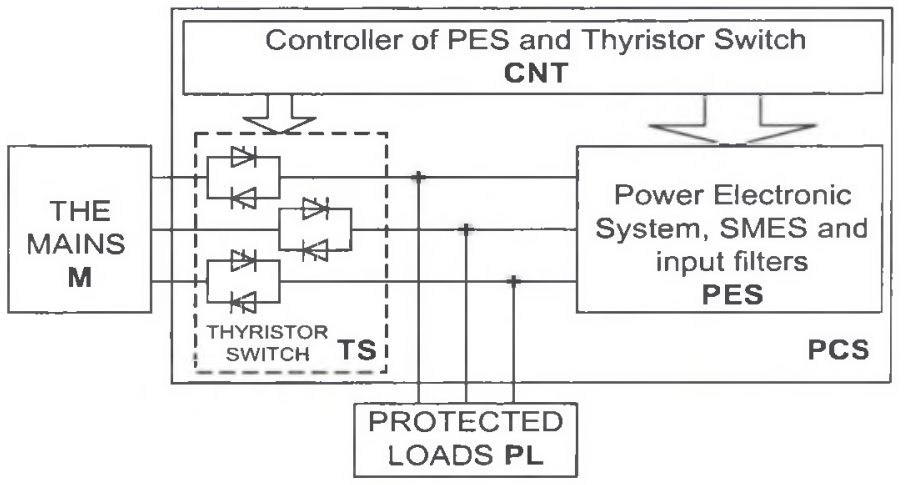

Fig. 1. Scheme of Power Conditioning System (PCS)

Rys. 1. Schemat prezentowanego kondycjonera mocy

The goals of the paper are as follows: i) analysis of the thyristor switch (TS) operation, in disconnection and reconnection modes of the PCS, ii) synthesis of the PCS control aiming at decreasing the TS turn off time. The methods for PCS control in case of one and three phase system are presented.

The PCS allows delivering energy to the protected loads not longer than for 1 second. Such short voltage disturbances predominate in the mains. After the voltage disturbance, the protected loads and the PCS should be reconnected to the mains. In order to limit the mains current at a reconnection moment the resynchronization process is needed. The realized resynchronization process and its influence on the protected loads voltage in transient state are presented in the paper. The time of resynchronization process is a trade-off between the amount of energy stored in the SMES and need for limitation of the mains currents at the reconnection moment.

The analysis was performed using Matlab-Simulink program. Finally, the experiment was carried out. It proved the correctness of control in disconnection and reconnection mode.

\section{DISCONNECTION MODE (DM)}

Disconnection mode (DM) of the PCS is a transient mode taking place between the compensation mode (CM) and the voltage fault mode VFM. In the CM, the PCS compensates the reactive power and reduces higher harmonics in the mains currents. Simultaneously, the PCS monitors the mains voltage space vector amplitude and if any voltage disturbance occurs (for time longer than $1 \mathrm{~ms}$ ), the control system cancels gate thyristor signals in the TS and starts operate in DM. 


\subsection{One-phase system}

A one-phase model of the PCS with the protected load and the mains is presented in Fig. 2. The main task in $C M$ is reactive power compensation where the PCS voltage $\left(\mathrm{V}_{\mathrm{PCS}}\right)$, is in phase with the load voltage $\left(\mathrm{V}_{\mathrm{LOAD}}\right)$ and the mains voltage $\left(\mathrm{V}_{\mathrm{LINE}}\right)$ (Fig. 3a). If voltage dip occurs, the PCS cancels the thyristor gate signals and changes control strategy from CM to VFM.

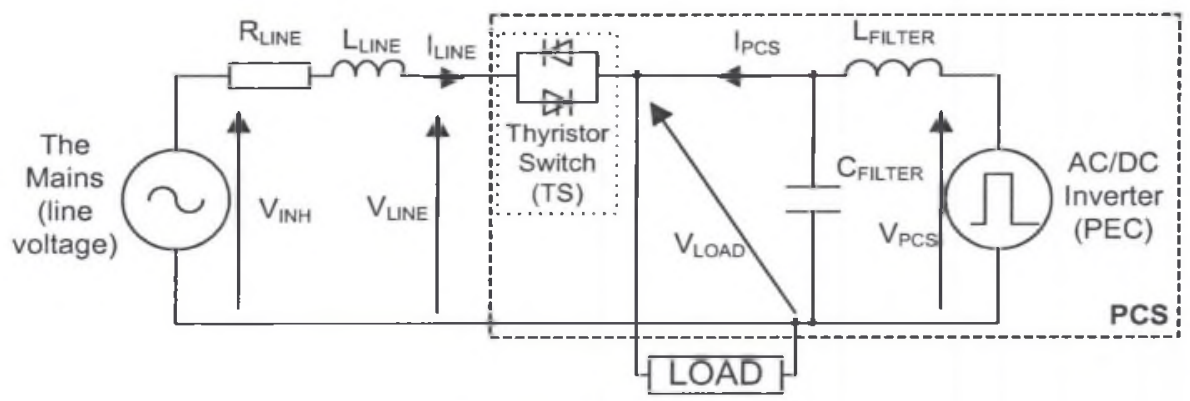

Fig. 2. One-phase model of the PCS

Rys. 2. Model jednofazowego kondycjonera mocy

In this mode the PCS generates a load voltage $\left(\mathrm{V}_{\text {LOAD }}\right)$ that follows the reference voltage from the controller (CNT) [8] (Fig. 3b). In such a system the inherent voltage $\left(V_{\mathrm{INH}}\right)$ is lower than the load one $\left(V_{\mathrm{LOAD}}=V_{\mathrm{LINE}}\right)$ and voltage drop across the line inductor $L_{\mathrm{LINE}}$ causes decrease in the line current $I_{\text {LINE }}$ to zero and ensures reversing voltage polarisation across the thyristors $\left(V_{\text {SWITCH }}\right)$, resulting in turning the thyristors off. It can be observed that the ensuring proper value of $V_{\text {LOAD }}$ by the PCS increases the line current decay. Owing to that the turn off time can be very short depending on the moment of the disturbance occurance and its depth.
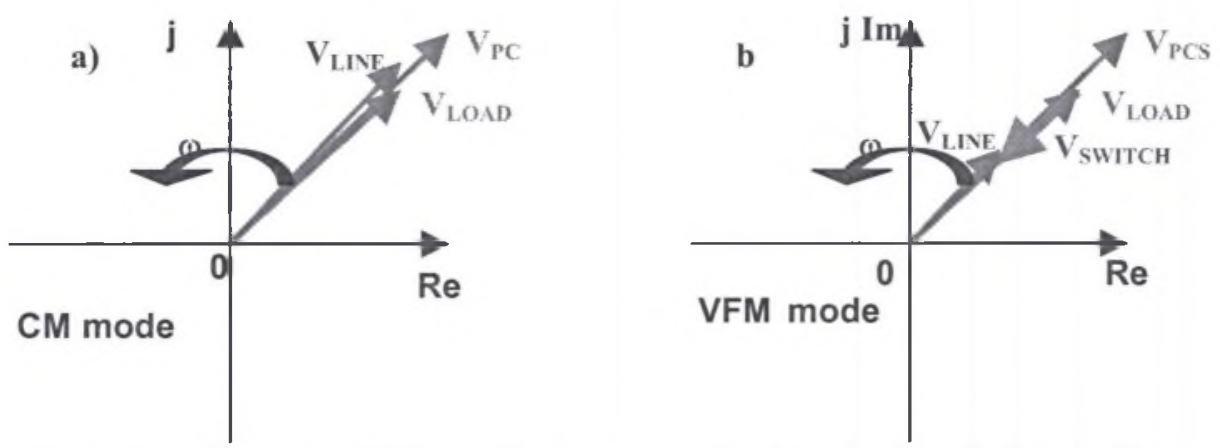

Fig. 3. Idea of one- phase PSC operation in compensation (a) and voltage fault mode (b)

Rys. 3. Jednofazowy kondycjoner mocy PSC - praca w trybie kompensacji (a) i zapadu napięcia (b)

In order to observe the process of disconnection, the simulation was performed. The results are presented in Fig.4 (for the following simulation parameters: $V_{\mathrm{LINE}}=230 \mathrm{~V}$, $\left.L_{\mathrm{LINE}}=0.1 \mathrm{mH}, R_{\mathrm{LINE}}=0.1 \Omega, R_{\mathrm{LOAD}}=15 \Omega, L_{\mathrm{LOAD}}=47.7 \mathrm{mH}, C_{\mathrm{FILTER}}=10 \mu \mathrm{F}, L_{\mathrm{FILTER}}=1 \mathrm{mH}\right)$. After the voltage dip- at $0.205 \mathrm{~s}$, the PCS cancels the gate signals of thyristors and changes its control strategy from CM to VFM which results in turning the thyristors off. From this moment the load voltage is controlled exclusively by the PCS using the energy stored in a HTS coil. In transient from CM to VFM, the load voltage oscillations can be observed. They are 
mainly caused by a filter capacitor and inductor $\left(\mathrm{C}_{\text {FILTER }}, \mathrm{L}_{\mathrm{FILTER}}\right)$. To reduce oscillations a damping resistor connected in series with the capacitor can be used. The damping resistor increases power losses. They are caused not only by the AC current component coming from the mains but also by the AC component of the current, generated by PWM shape PCS voltage.

It is obvious that in a one-phase system there is no need to apply any additional control strategy, apart from switching CM to VFM, because thyristors are switched off autonomously owing to the load voltage $V_{\text {LOAD }}$ which is higher than the inherent one $V_{\mathbb{I N H}}$.

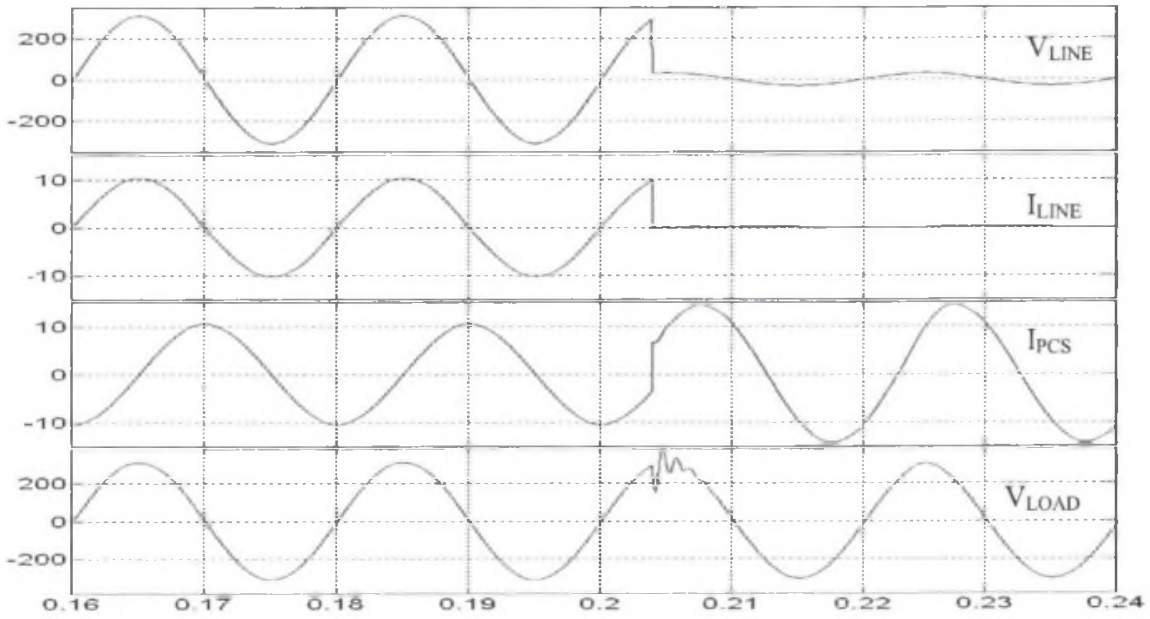

Fig. 4. Simulation of voltage dip at time $0.205 \mathrm{~s}-$ one phase PCS

Rys. 4. Jednofazowy kondycjoner mocy - badania symulacyjnie zapadu napięcia $(t=0,205 \mathrm{~s})$

\subsection{Analysis of a three-phase system}

Three control methods of three phase PCS are presented in the section:

- Method I - Direct Method, based on direct transient from CM to VFM (as described for a one-phase system)

- Method II - Wait State Method, based on inserting no operation state between CM and VFM, waiting for natural turn off of the thyristors.

- Method III - Active Method, based on active taking over the load current from the mains by the PCS.

In all these methods after voltage disturbance is detected the controller (CNT) cancels gate signals of thyristors.

Method I (idea presented in section 2.1) has been tested in three phase system. This method assumes direct transient from CM to VFM after detection of a voltage dip or short interruption. Unfortunately, this method does not operate properly in three phase, three wires systems. This is because at the beginning of turning off process, the thyristor in one phase is turned off quickly leaving two others still conducting. Because the PCS control is based on space vector approach, the operation with thyristors conducting in two phases results in incorrect operation of the PCS (nonsymmetrical supplying with low impedance of the mains connected in parallel with the load). The turn off process can take even much more time than $10 \mathrm{~ms}$. The simulation results of this disconnection method are depicted in Fig. 5a. It should 
be noted that the turn off time is longer than $10 \mathrm{~ms}$. In order to reduce the turn off time in the TS two other the PCS control methods can be applied

In Method II, after detection of a voltage disturbance, the PCS decreases its input currents to zero and waits $10 \mathrm{~ms}$ when the natural turn off of thyristors takes place. At that moment the PCS starts operating in VFM mode. The relatively long turn off time cause that this method is not a satisfactory solution (the simulation results of Method II are presented in Fig. 5b). The load voltage in this method is equal to the line voltage until the moment of switching off the thyristors and after that equals zero up to the moment the PCS starts VFM mode. It is also unacceptable. In Method III the PCS, after detection of a voltage disturbance, starts to supply the load with the required active and reactive current components (such as before the voltage disturbance). This causes reducing the line currents to zero. The PCS runs this operation mode for a few milliseconds (about $2 \mathrm{~ms}$ ) in order to obtain firm off state of the thyristors. Just after that PCS starts to operate in VFM, which means that PCS controls the voltage across the load. This method gives the best results (see Fig. 5c). The total time from the start of detecting the voltage disturbance till the start the PCS VFM mode is about $3 \mathrm{~ms}$ and it is the worst case.
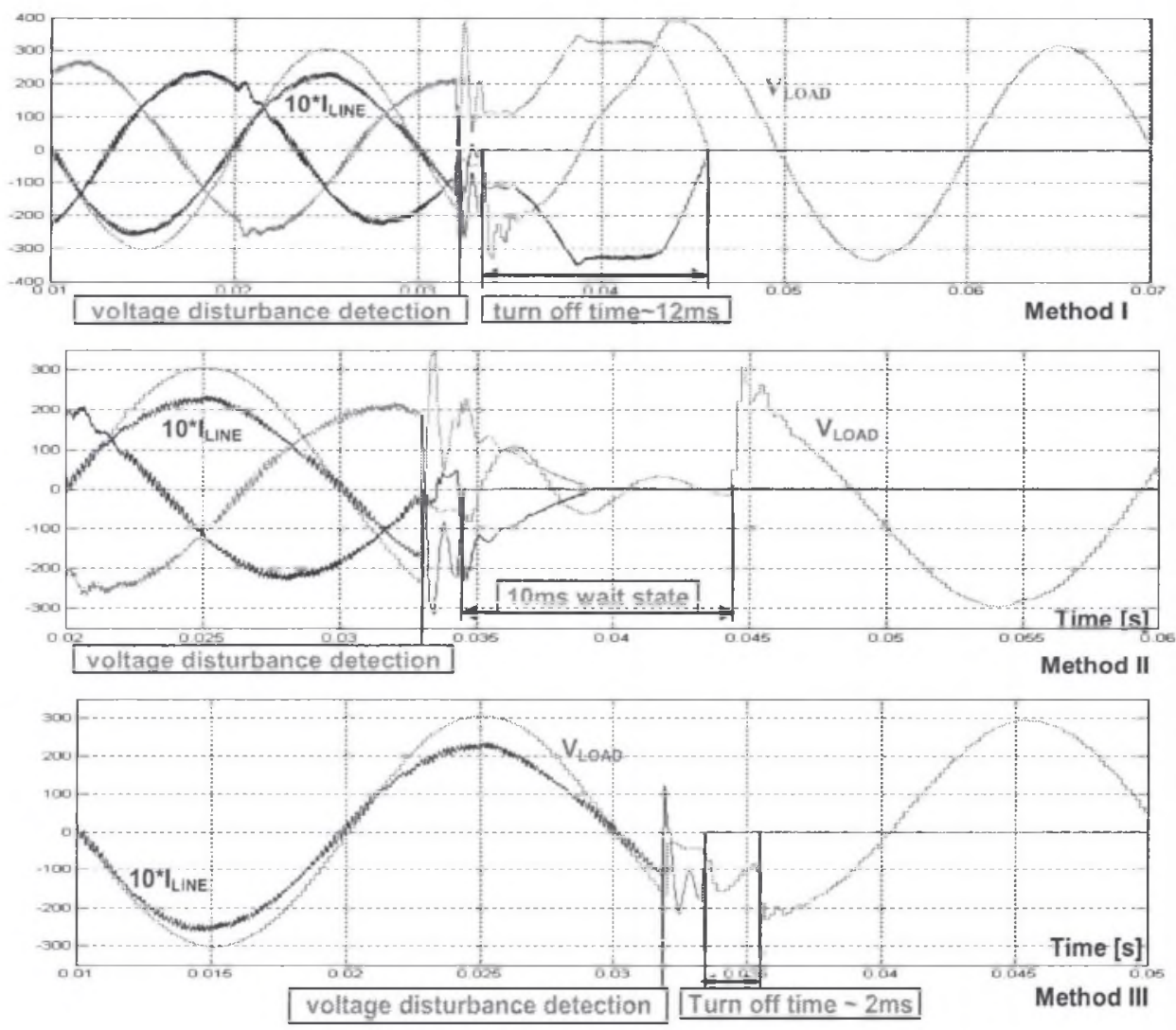

Fig. 5. Simulation results of different disconnection methods: (a) - method I, (b) - method II, (c) - method III

Rys. 5. Badania symulacyjnie różnych metod odłączania: (a) - metoda I, (b) - metoda II, (c) metoda III 
Operation of the PCS in transient from CM to VFM is presented in diagram in Fig. 6. The diagram presents all operation conditions. Because of its advantages, Method III has been realised in a real system. Its advantages have been confirmed by experiments results of which are presented in Section 4.

The method being suitable for linear loads does not give very good results for strongly nonlinear loads (like thyristor bridge rectifiers). For such loads active and reactive current components vary in time and Method III results in a distorted load voltage in transient.

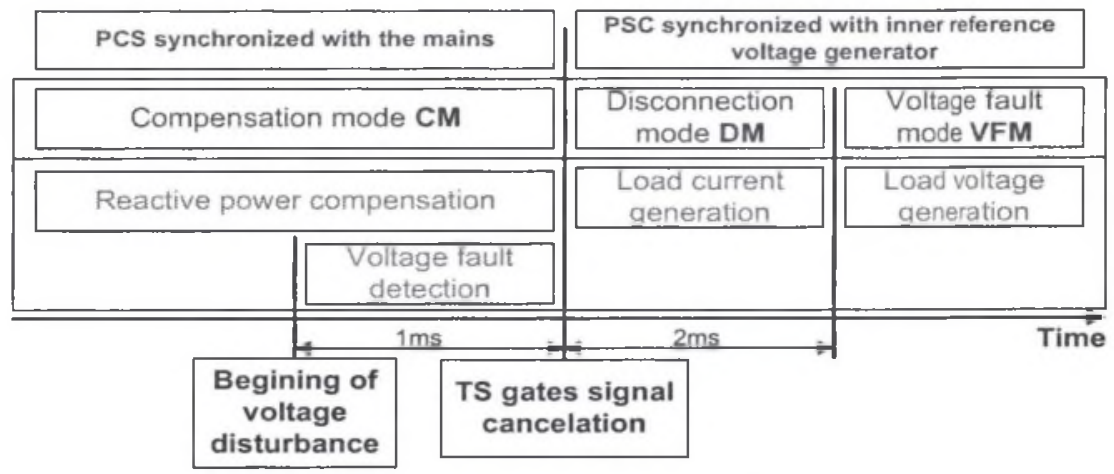

Fig. 6. Method III (the best one) - operation of PCS in transient from CM to VFM

Rys. 6. Przejście kondycjonera $\mathrm{z}$ trybu kompensacji do trybu zapadu napięcia dla metody III

\section{RECONNECTION MODE (RM)}

Reconnection mode (RM) of the PCS is the transient mode, taking place between the voltage fault mode (VFM) and compensation mode (CM). Just after a voltage disturbance decays, the load and the PCS have to be reconnected to the mains. In such a case the PCS starts operation of $\mathrm{CM}$ and at the same time superconducting coil starts to be recharged. If any phase shift between the load and the mains voltages occurs during reconnection process it will cause a current peak. To reduce this peak - reconnection should be made after resynchronization process. Because of the limited amount of energy stored in the SMES coil the resynchronization process has to be as short as possible (it was assumed that resynchronization process takes $10 \mathrm{~ms}$ ). The idea of resynchronization process and operation of the PCS in reconnection mode (RM) is presented in diagram in Fig. 7. At the beginning the PCS operates in VFM mode constantly monitoring the mains voltage. If the mains voltage space vector amplitude is higher than 90 percent of its nominal value for the time longer than $20 \mathrm{~ms}$, the PCS starts resynchronization process. The time of $20 \mathrm{~ms}$ prevents from a one phase voltage dip. The resynchronization process takes $10 \mathrm{~ms}$ and after that the PSC turns on the TS and starts CM operation.

If any phase shift between the voltages $V_{\text {LINE }}$ and $V_{\text {LOAD }}$ exists at the beginning of resynchronization process $(\Delta \varphi-$ in Fig. $7 b)$ the load voltage frequency is changed to value resulting in zero phase shift at the end of resynchronization.

During resynchronization the phase of $\mathrm{V}_{\mathrm{LOAD}}$ is computed by the incremental algorithm, equation (1):

$$
\varphi_{V I L A D}(k+1)=\varphi_{V L O A D}(k)+2 \pi f \cdot T_{i}+\frac{\Delta \varphi}{0.01} \cdot T_{i},
$$


where:

$\varphi_{\mathrm{VLOAD}}(\mathrm{k})$ - phase at time $(\mathrm{k})$,

$2 \pi f \cdot T_{i}$ - phase incrementation (frequency multiplied by computation time),

$\frac{\Delta \varphi}{0.01} \cdot T_{i} \quad$ - phase correction ensuring zero phase shift after $10 \mathrm{~ms}$

a)

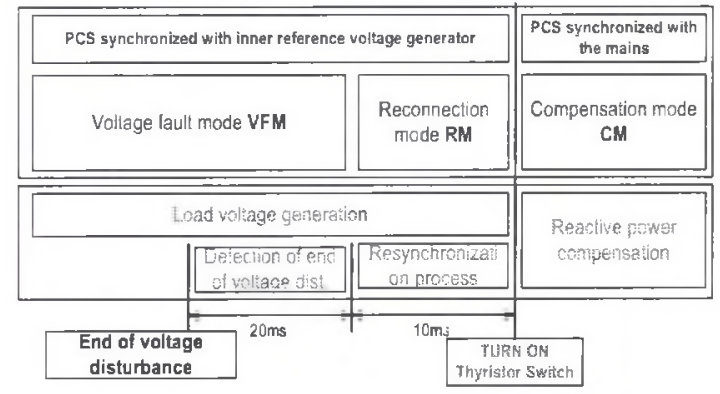

b)

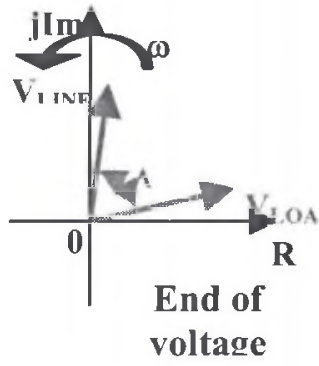

Fig. 7. Operation of PCS in reconnection process (a) and idea of resynchronization process (b)

Rys. 7. Proces ponownego podłączenia kondycjonera do sieci (a) idea resynchronizacji (b)

The maximum phase difference $\Delta \varphi$ appears if the line and the load voltage are in opposition. It causes, that for $10 \mathrm{~ms}$ resynchronization, frequency change is $50 \mathrm{~Hz}$. The frequency change has no effect when the protected load is passive (for example RL load). For other loads (like squirrel cage induction machines) that frequency change can cause short operation disturbances. Fortunately these disturbances are smaller than those caused by a sudden voltage phase change that can occur without resynchronization process. Additionally, the PCS is designed for elimination voltage disturbances shorter than 1 second and thanks to that the phase shift between the voltages $V_{L O A D}$ and $V_{L I N E}$ at the end of disturbance is relatively small. Some experimental results of the reconnection mode are presented in Section 4.

\section{EXPERIMENTAL RESULTS}

The presented method of disconnecting the protected load and the PCS from the mains as well as resynchronization and reconnection process were tested in a laboratory. The PCS parameters are as follows: nominal power $S_{\mathrm{N}}=30 \mathrm{kV} \cdot \mathrm{A}$, nominal voltage $V_{\mathrm{N}}=400 \mathrm{~V}$, nominal energy $E_{\mathrm{N}}=21 \mathrm{~kJ}$. The signal controlling the thyristor switch TS was generated by a PCS controller, based on a DPS microcontroller TMS320F2812. Two types of loads were used, connection of resistor and inductor in series and a $3 \mathrm{~kW}$ asynchronous motor.

The voltage disturbance response of the PCS is presented in Fig. 8. It can be noted that after the line voltage disturbance, the line current smoothly decreases to zero and thyristors are switched off.

The advantage of this method is that there are no load voltage or current disturbances in transient. The load voltage amplitude after voltage fault is lower (the effect of lack of higher voltage harmonics in the line voltage in the laboratory). The PCS controlled with method III operates correctly with both kinds of loads. Some current oscillations and ripples can be observed in Fig. 8. Ripples are caused by the PCS switching frequency. The relatively long record time (low oscilloscope sampling frequency) results in oscillations in the line current 
waveform while they do not exist. The long record time was needed to capture the transients.. The experimental result of resynchronization procedure is shown in Fig. 9. After the voltage disturbance decays $(10 \mathrm{~ms})$, the system detects the end of the voltage disturbance for 20 milliseconds (prevention from a one phase voltage dip) and then starts synchronizating the load with the mains. It was assumed that resynchronization should not be longer than $10 \mathrm{~ms}$. It can cause increase in the load current amplitude in case of supplying an induction motor (electromagnetic field transient) but has no effect on an RL load (Fig. 9).

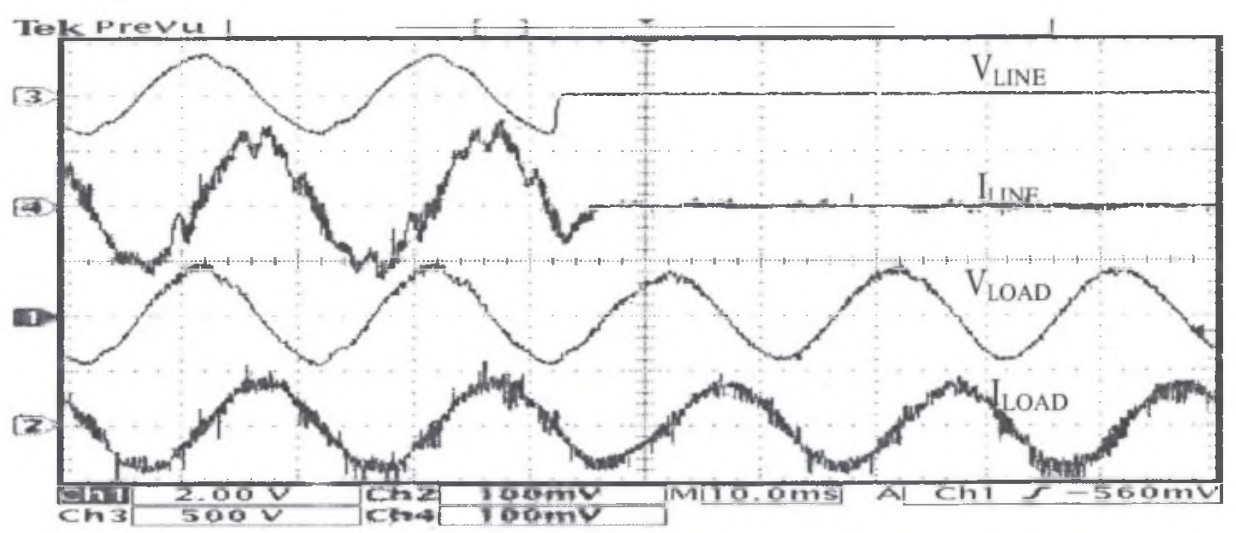

Fig. 8. Experimental results of disconnection of three phase PCS (RL load)

Rys. 8. Wyniki eksperymentalne dla procesu odłączania trójfazowego kondycjonera obciążenie RL)

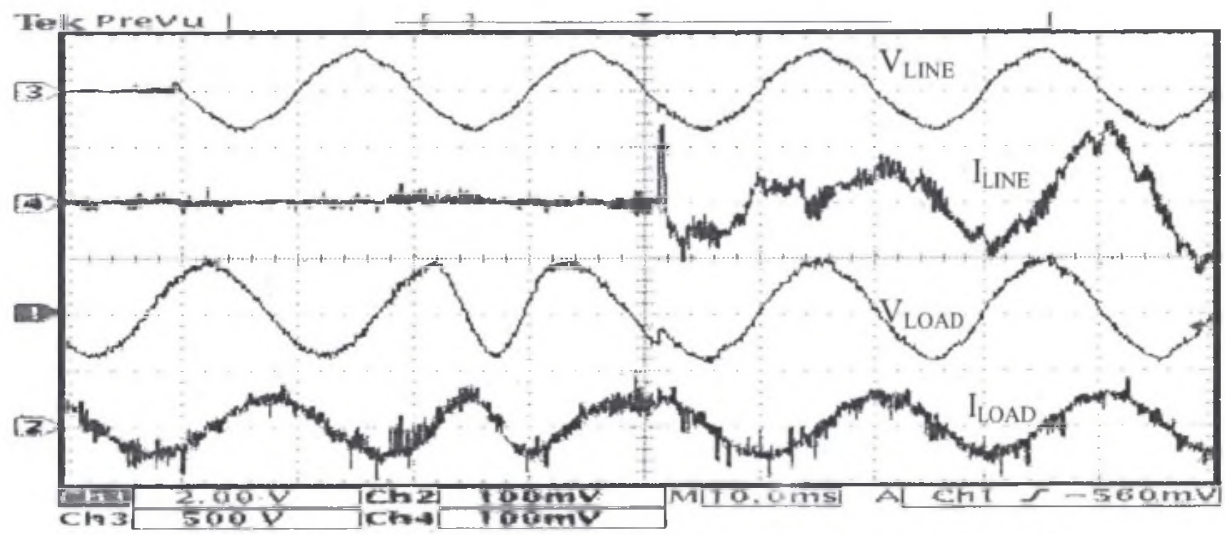

Fig. 9. Experimental results of reconnection of three phase PCS (RL load)

Rys. 9. Wyniki eksperymentalne dla procesu podłączania trójfazowego kondycjonera (obciążenie RL)

The depicted resynchronization process is close to the worst case with the voltages $V_{\text {LOAD }}$ and $V_{\text {LINE }}$ in opposition. In other experiment for the voltage dip that lasted about 1 second the phase shift between the voltages was close to zero. After resynchronization gate signals are applied to the thyristors and the PCS generates voltage that is in phase with the mains voltage. Because it is impossible to control the exact moment of turning on the thyristors it is assumed that the PCS operates as a voltage source for $10 \mathrm{~ms}$ (it was neglected in diagram 7 to ensure better simplicity). After that the PCS starts operating in CM. Because the small phase shift between the voltages $V_{\text {LINE }}$ and $V_{\text {LOAD }}$ still exists, caused by delays in the control system and 
PI controllers used in VFM mode [8], a current peak occurs at the moment of reconnection. This peak has a limited value.

\section{CONCLUSIONS}

1. The disconnection and reconnection of the protected loads together with the PCS from the mains were analysed separately.

2. Among the analysed PCS control methods in disconnection mode the method III proved to be the best one.

2.1 It gives the fastest switch over the protected load from the mains to the PCS with the smallest disrupting of the operation of the protected loads.

2.2 It is suitable for linear loads. It could be also used for nonlinear loads. (like thyristor bridge rectifiers) giving slightly worse results.

3. The proposed reconnection method including resynchronization meets requirements.

3.1. It limits a current peak at the reconnection moment using resynchronization.

3.2. It gives as fast as possible switch over the protected load from the PCS to the mains with the smallest disrupting of the operation of the protected loads.

3.3. For such loads like asynchronous motors the resynchronization process can influence its operation.

4. The proposed control method of the PCS in disconnection and reconnection modes was tested in a real PCS. The experiment results verified its advantages.

\section{REFERENCES}

1. Casadei D., Grandi G., Reggiani U., Serra G., Tani A.: Analysis of a Power Conditioning System for Superconducting Magnetic Energy Storage, Industrial Electronics, 1998. Proceedings. ISIE '98. IEEE International Symposium on , Volume: 2, 7-10 July 1998 ,pp. 546 -551.

2. Casadei D., Grandi G., Reggiani U., Serra G., Tani A.: Behaviour of a Power Conditioner for $\mu-S M E S$ Systems Under Unbalanced Supply Voltages and Unbalanced Loads, ISIE'99, Bled, Slovenia, 1999, pp. 539-544.

3. Doht H.-Ch., Hilscher M., Prescher K., Unterlass F.-J.: Design and Behaviour of a Superconducting Energy Management Systems (SEMS) for Industrial Power Quality Applications, EPE'99, Lausanne, Switzerland.

4. Liu Ping, Kang Yong, Dai Ke, Zhang Hui, Chen Jian: Design and Performance of a Prototype Power Conditioning System (PCS) for Superconducting Magnetic Energy Storage (SMES), EPE-PEMC 2000, Kosice, Slovak Republic, 2000, Vol. 4, pp. 221-225.

5. Schottler R.: Voltage Sag Protection for Sensitive Loads, PCIM 2001, Nuremberg, Germany

6. Blacha N., Barnhusen H., Salbert H., Malcher S.: Some Experiences with SMES and Supercapacitors in UPS Applications, PCIM 2001, Nuremberg, Germany.

7. Hassan I.D., Bucci R.M., Swe K.T.: 400 MW Smes Power Conditioning System, Part I-Performance Requirements andConfiguration, Part II - Operation and Dynamic Performance, PESC'91, 22nd Annual IEEE, 24-27 June 1991, pp.338- 353.

8. Biskup T., Bührer C., Grzesik B., Krijgsman J., Michalak J., Pasko S., Stepien M., Zygmanowski M.:Control System of Power Conditioning System with Superconducting Magnetic Energy Storage in Different Operation Condition, EPE-PEMC'04, 2-4 September 2004, Riga, Latvia.

The paper was presented on $11^{\text {th }}$ European Conference on Power Electronics and Application, 11-14 September 2005, Dresden, Germany. 